\title{
Monitoring diet and diet-related chronic disease risk factors in Finland
}

\author{
Satu Männistö ${ }^{1, *}$, Tiina Laatikainen ${ }^{1}$, Satu Helakorpi ${ }^{2}$ and Liisa M Valsta ${ }^{2}$ \\ 'Department of Chronic Disease Prevention, National Institute for Health and Welfare, PO Box 30, Fl-00271, \\ Helsinki, Finland: ${ }^{2}$ Department of Lifestyle and Participation, National Institute for Health and Welfare, \\ Helsinki, Finland
}

Submitted 20 July 2009: Accepted 15 March 2010

\begin{abstract}
Health and dietary monitoring has a long history in Finland. The aim of this review is to summarise the main sources of Finnish dietary information including food balance sheets, household budget survey data, questionnaires related to dietary behaviour and risk factors of main chronic diseases as well as dietary surveys. According to these sources, dietary behaviour and food choices have changed considerably during the last decades. For example, the total fat intake (E\%) has decreased remarkably from nearly $40 \%$ in the late 1960 s to close to $30 \%$ in 2007. Furthermore, the type of fat consumed has changed noticeably due to the increased popularity of oil used in cooking and the large variety of softer spreads available. There has also been a notable decrease in intake of salt, and a multiple increase in the consumption of fruits and vegetables since the 1970s. The future challenges of dietary monitoring include keeping the participation rates in dietary surveys at acceptable levels, controlling under/over-reporting of diet, developing a national monitoring system for children and adapting to international changes and requirements to harmonise dietary monitoring in Europe.
\end{abstract}

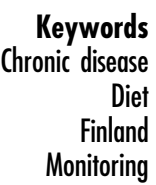

\section{Methods of dietary monitoring in Finland}

The three main levels of aggregation of dietary information are national food availability, household food availability and individual food consumption. In dietary monitoring, the individual food consumption may be further divided into quantitative measurements obtained in food consumption and dietary surveys as well as semiquantitative or qualitative measurements describing dominant food choices and behaviour-related measures obtained by questionnaires or interviews. In Finland, all these sources of information have been used for dietary monitoring purposes. The long-term trends of food consumption and nutrient intake have shown many notable changes in Finnish diet during the last decades.

\section{National food availability data}

Data on available food commodities, per capita consumption, have been compiled annually since the crop year 1949/1950 and since 1970 based on the calendar year in the form of food balance sheets. The Statistical Group of the Information Centre at the Ministry of Agriculture and Forestry (Tike) is the official authority responsible for collating the agricultural statistics in Finland and it publishes the food balance sheets ${ }^{(1)}$. These data provide essential information on the national food system, including domestic supply (production, imports and exports), domestic utilisation (use of the commodity for feed, seed, processing, waste and food), and per capita values for the supply of all commodities ( $\mathrm{kg} /$ person per year).

The information presented in the balance sheet is mainly compiled from the statistics of the Information Centre of the Ministry of Agriculture and Forestry, Finnish Food and Drink Industries' Federation, the National Board of Customs and the Finnish Game and Fisheries Research Institute. The Balance Sheet for Food Commodities summarises the production, domestic use and consumption of eleven food product groups (cereals, potato, sugar, legumes, vegetables, fruit and berries, meat, eggs, fish, milk products, fats) and beverages. Consumption of food commodities is presented on a national level and as an average per person. In addition, nutritional content of food, i.e. protein, fat and energy, is also analysed. The food balance sheet is compiled in accordance with the classification structure of the FAO of the United Nations. Food availability, however, is a crude measure that does not take into account the amount of food that goes unconsumed.

The food balance sheet data have shown the major consumption changes in the Finnish diet since 1950, i.e. a major decrease of cereal and potato consumption between 1950 and 1975, a tripling vegetable consumption starting in the early 1970 s as well as a quadruple increase in 


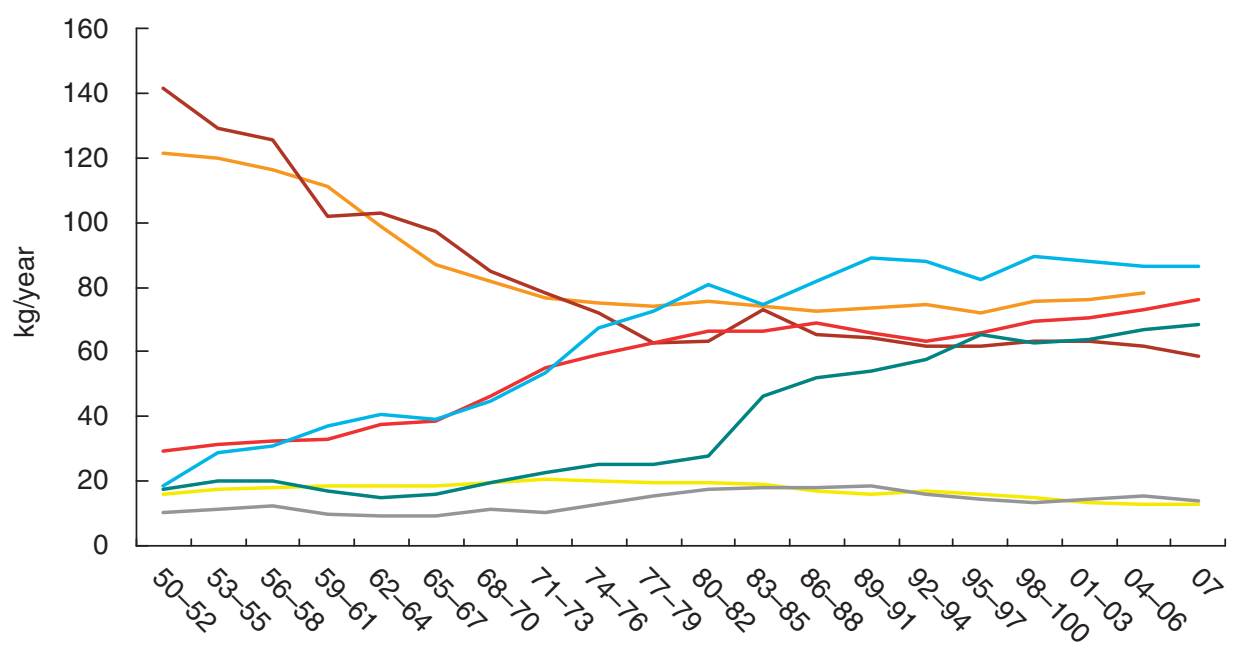

Fig. 1 Selected trends of food availability in 1950-2007 according to food balance sheets: $\_$, cereals; — — potato; - , fats; $\longrightarrow$, meat; $\_$, fish; $\_$, fruits and berries; $\_$, vegetables

fruit consumption throughout the years 1950-1990 (Fig. 1). Milk consumption was very high, at about 11 /person per day (about $350 \mathrm{~kg} /$ person per year) in the 1950s, but has decreased to half at the end of the 1950s, and then again at the end of the 1970s (Fig. 2). Conversely, the consumption of cheese has more than doubled during the last 30 years. The changes in butter and milk consumption have substantially accounted for the changes in fat consumption and quality in Finland, although the reduction of fat intake from milk and butter has been partly balanced by increased cheese consumption.

\section{Household budget surveys}

Statistics Finland has collected food purchase data of households from the household budget surveys between 1966 and 1998, as amounts, and in 2006 as consumption expenditure of specific foods. The 2006 data has been further divided by the corresponding unit prices to produce comparable data for consumption trends. Altogether seven surveys have been carried out in 40 years and the trend results published recently ${ }^{(2)}$. In these studies, the consumption of foods includes foods purchased from shops to take home and self-produced or collected foodstuffs. However, it does not include information concerning eating outside the home, or take-away meals. The food expenditure data have been classified according to the COICOP-HBS classification in which the number of food classes was over $250^{(2)}$. The results are presented by household type, age group, region and socio-economic group.

The results from the household budget surveys show in part trends of the same kind as the food balance sheet data, e.g. decreased consumption of milk, potatoes and cereals, and increased consumption of fruit and soft drinks (Fig. 3). The household budget survey data show also that the

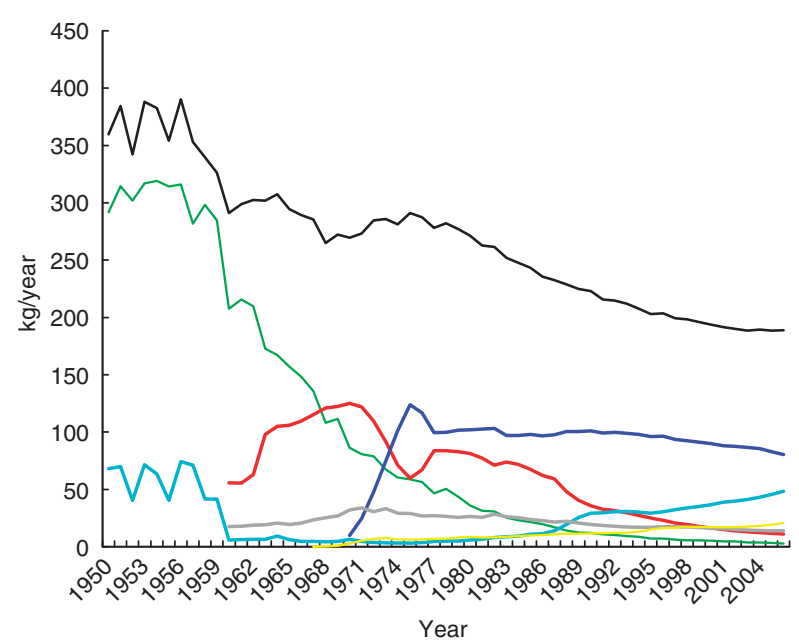

Fig. 2 Consumption of liquid milk products 1950-2006 according to food balance sheets: _- whole milk (used on farms); $\_$, whole milk; $\_$, low-fat milk; $\_$, skimmed milk; $\ldots$, sour milk; —_, yoghurt; —_, liquid milk, total

consumption of bread (about $35 \mathrm{~kg} /$ person per year) has not changed during the last 40 years, but consumption of flour and cereals has decreased to less than one third its previous level, from $57 \mathrm{~kg}$ to $15 \mathrm{~kg}$, indicating decreased baking and preparation of cereal foods at homes. Consumption of sugar has also decreased to a third of its level in the 1960s according to the household budget survey data. The food balance sheet data, on the other hand, shows similar sugar consumption levels between the $1950 \mathrm{~s}$ and the early 2000s. These data are indications of a fall in the acquisition of ingredient type of foods and increased consumption of processed food, which is in accordance with the decreased food and meal preparation at homes during the past decades. The purchases of preserved and prepared foods have grown between 1966 and 2006, 


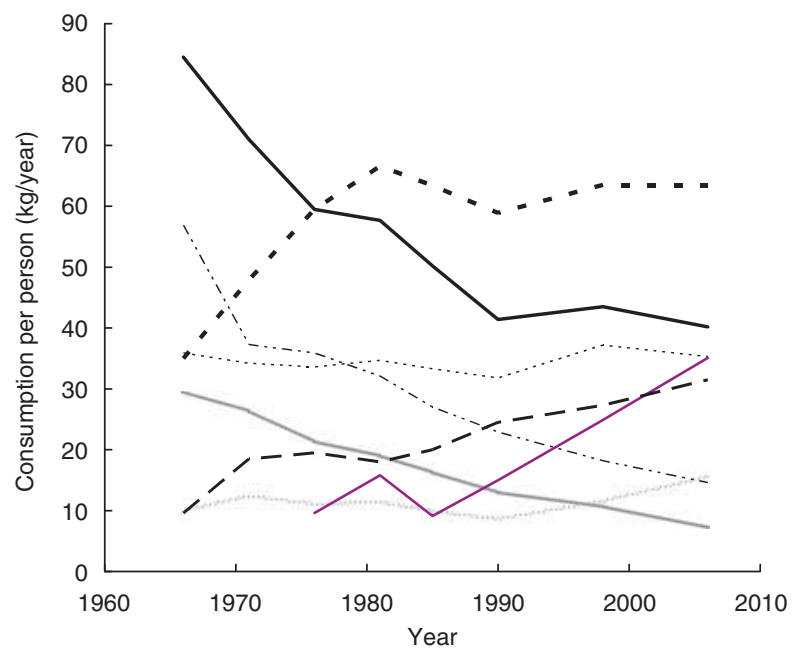

Fig. 3 Selected trends of food consumption in 1966-2006 according to household budget surveys: - - -, flour flakes; ....., bread; ........, sweet bakery products; - -, fresh fruit and berries; $\_$, fruit juice; $\longrightarrow$, potatoes and potato products; .mmmmm, sugar and syrup; - - , soft drink (I)

according to the household budget surveys, from about $6 \mathrm{~kg}$ to $29 \mathrm{~kg}$ (person/year). Purchases of ingredient type of foods were greater in older age groups than younger ones. The consumer expenditure on eating outside the home was larger in younger age groups compared with older ones. Popular foods in the more urban metropolitan area were cheese, greenhouse vegetables, fruit, pastry and cakes, pasta, pizza and mineral water, and less popular foods were milk, potatoes, sausage, wheat flour, sugar and fat spreads, compared with the other areas of the country. Geographical differences were also indicated ${ }^{(2)}$.

\section{Questionnaires related to dietary behaviour}

Postal surveys of health behaviour were first carried out in Finland biannually in North Karelia during the beginning of the project period in 1972-1977. Since 1978, this approach has been widened to cover the whole of Finland, and the health behaviour and health among the Finnish adult population surveys have been conducted annually from a random sample of the adult population between 15 and 64 years of age ${ }^{(3)}$. Each year the sample size has been about 5000. Since 1985, a similar approach was adopted for the elderly population, aged 65-79 (later 84) years. These postal surveys have been carried out every second year for a stratified random sample of 1800 (since 1993, 2400) persons ${ }^{(4)}$.

Both these surveys have included self-administered questions on diet and eating habits. The main aim has been to gather information on eating habits such as frequency of eating and snacking, eating places, use of worksite restaurants and catering services; and also information on food choices, such as type of fat used in cooking, type of milk or bread spread usually consumed, drinking habits and use of food supplements. These surveys have also included short food frequency questionnaires on the most common food items.

These repeated measures have enabled the observation of the changes in food habits, at population level that have resulted from active nutrition policies, legislative changes, recommendations and programs. As an example, illustrated in Fig. 4, the 35-year trends in dietary habits (eating vegetables daily, drinking skimmed milk or milk with $1 \%$ fat and using butter on bread) are presented from the health behaviour and health among the Finnish adult population surveys ${ }^{(3)}$.

\section{Health examination surveys including dietary surveys}

Different population-based surveys on diseases, risk factors and related health behaviours have been carried out in Finland regularly since late 1960s. The first large-scale study was the Finnish Mobile Clinic Health Examination Survey during 1966-1972 (baseline study) with over 51000 participants over 15 years of age, arranged by the Social Insurance Institution ${ }^{(5)}$. Food consumption of 10054 participants was assessed using a dietary history interview $^{(6)}$. The reexamination study of the Finnish Clinic Health Examination Survey was conducted during 1973-1976 with over 17000 participants. The aim of the present study was to assess comprehensively the health status and functional capacity of the Finnish adult population. The cohort was also followed up in 1973-1976. Later there were similar large studies, first the Mini-Finland study from 1977 to 1981 with 7200 participants over 30 years of age ${ }^{(7,8)}$, and more recently the Health 2000 survey, carried out in years 2000 and 2001, with a representative sample of about 10000 participants aged

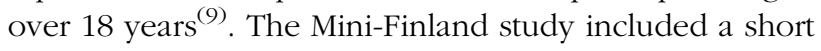
questionnaire on dietary factors, whereas the Health 2000 survey included both questionnaires on dietary behaviours and a validated food frequency questionnaire with 128 food items to measure the subject's diet as a whole ${ }^{(10)}$.

Cross-sectional population surveys mainly concerning cardiovascular risk factors have been carried out in Finland since 1972 at 5-year intervals. These surveys that were established to evaluate the effects of the North Karelia project ${ }^{(11)}$, later served the purposes of the WHO MONICA project ${ }^{(12)}$, and have recently been developed into a national risk factor monitoring approach, the National FINRISK study ${ }^{(13,14)}$. This health monitoring system, launched in the provinces of North Karelia and Kuopio in the east in 1972, now covers the regions of North Karelia, Northern Savo (former Kuopio province), Turku and Loimaa in the south-west, the capital area including Helsinki and Vantaa, and also provinces of Oulu and Lapland in the north. The survey sample of the 

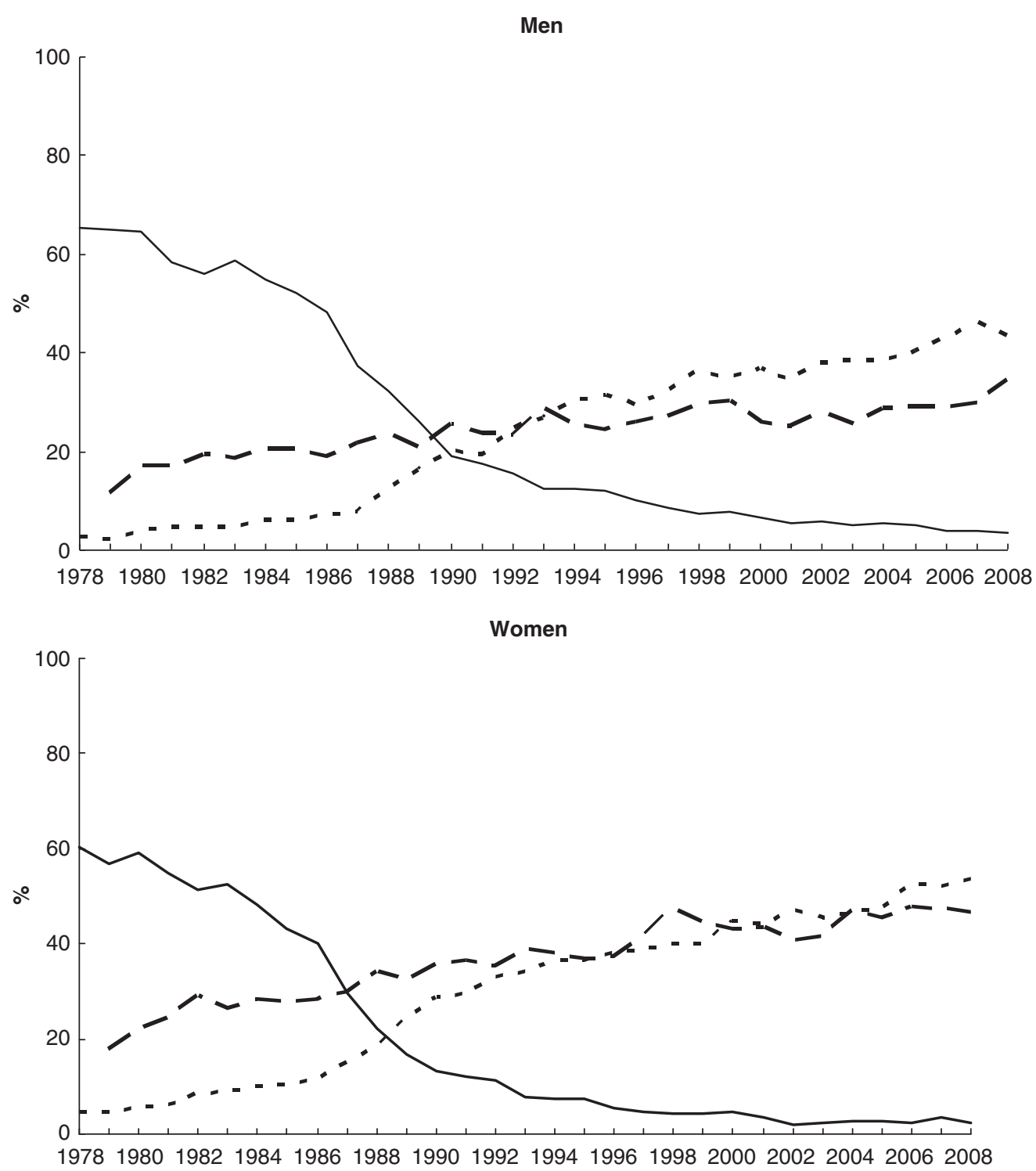

Fig. 4 Proportion (\%) of those eating vegetables daily, drinking skimmed or $1 \%$ milk (1\% fat) and using butter on bread among 15-64-year-old population in Finland in 1978-2008: - - , butter on bread; - - , vegetables daily; - - - -, skimmed or 1\% milk

adult population aged 25-64 (later 74) years has been stratified by area, sex and 10-year age groups, and has varied between 6000 and 13500 in different survey rounds. All these surveys have included questions on dietary behaviour and also short food frequency questionnaires. More detailed information on diet has been collected in sub-studies of the National FINRISK study, such as the national FINDIET survey by diaries, recalls and laboratory samples.

\section{The national dietary surveys}

The national FINDIET surveys conducted by the National Institute for health and welfare (previously the National Public Health Institute) have followed the food consumption and nutrient intake among the Finnish adult population

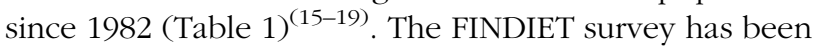
a part of the National FINRISK study, which monitors the risk factors of chronic diseases regularly every 5 years $^{(13,14)}$. The dietary surveys have included about $30 \%$ of those participants invited to participate in the National FINRISK study, i.e. 1300-2900 men and women per survey (Table 1). The participation rates have ranged from $60 \%$ to $72 \%$. The design and methods used in the latest dietary survey in 2007 are described in more detail elsewhere in this issue ${ }^{(20)}$.

Three-day food records were used in the two earliest FINDIET surveys (Table 1). Portions were estimated first by weighing, and later by household measures and validated picture booklets. In the FINDIET 1997 survey, the method was changed into a $24 \mathrm{~h}$ recall approach to 
increase the participation rate. Furthermore, trained interviewers were able to increase the accuracy and reliability of the gathered information by asking targeted questions. In the two latest surveys, the $48 \mathrm{~h}$ recall method was used with additional 3-6d estimated food record data collected in a subsample to enable habitual nutrient intake estimations and intake distribution modelling ${ }^{(20,21)}$. Thus, the changes in the dietary methods should be taken into account when the trends of food consumption and nutrient intake are interpreted. Figure 5 shows favourable trends especially in total fat and saturated fat intake (E\%) in Finland during the last decades based on the FINDIET survey data, which correspond to the trends of food balance sheet data on milk fat consumption. The main results of the recent FINDIET 2007 survey are described in detail elsewhere in this issue ${ }^{(21)}$. The future challenges for dietary surveys include keeping the participation rates in dietary surveys at acceptable levels and controlling under/over-reporting of diet. It has been summarised in the literature that $2-85 \%$ of participants under-reported and 1-39\% over-reported their energy intake (EI) depending on study population ${ }^{(22)}$. Data from a Swedish dietary survey showed that participants with an implausible low EI/BMR ratio (underreporters) reported lower intake of fat $(\mathrm{E} \%)$, saturated fatty acids (E\%) and carbohydrate (E\%), but higher intake of protein $(\mathrm{E} \%)^{(23)}$. Instead, Irish data with more strict definition of under-reporters than the Swedish data found no differences between the intakes of macronutrients with and without under-reporters. It has also been shown that under-reporters had dietary habits closer to recommended levels, such as lower fat intake and higher fibre intake, than those with acceptable energy intakes ${ }^{(24)}$. This was due to less frequent consumption, a larger proportion of non-consumers and smaller portion sizes. In Finland and in the United States, under-reporting has been found to be very similar between different kinds of food items, and the results seem to be comparable both with and without under-reporters ${ }^{(25,26)}$. In addition, when the results are presented per unit of energy (MJ) or as a percentage of total energy, the under-reporting issue is for the most part mastered.

The national FINDIET surveys include information on daily meals, average food consumption and nutrient intakes as well as food sources of nutrients (Table 1) ${ }^{(19)}$. The latest survey in 2007 also included some new features, such as participants aged 65-74 years and nutrient intake distributions. Furthermore, for the first time all participants who took part in the national FINRISK/FINDIET survey 2007 were invited 3 months later to participate in the second health examination of the DILGOM obesity cohort (dietary, lifestyle and genetic determinants of obesity and metabolic syndrome). During the second health examination, all participants filled in a food frequency questionnaire that measured the subject's usual diet over the previous 12 months. 


\section{Monitoring of nutrient status}

Monitoring of nutrient status in Finland has been restricted to some important nutrients. Urinary excretion of iodine was first investigated by Artturi I. Virtanen in the $1940 \mathrm{~s}^{(27)}$. Sodium intakes have been monitored by $24 \mathrm{~h}$ urinary excretion measurements in four risk factor surveys since the late $1970 \mathrm{~s}^{(28)}$. The low level of selenium in the Finnish soil and disturbingly low intakes of selenium were the reason for the enrichment of fertilisers with selenium in 1984, and the selenium status of different population groups have been monitored by a special monitoring programme since

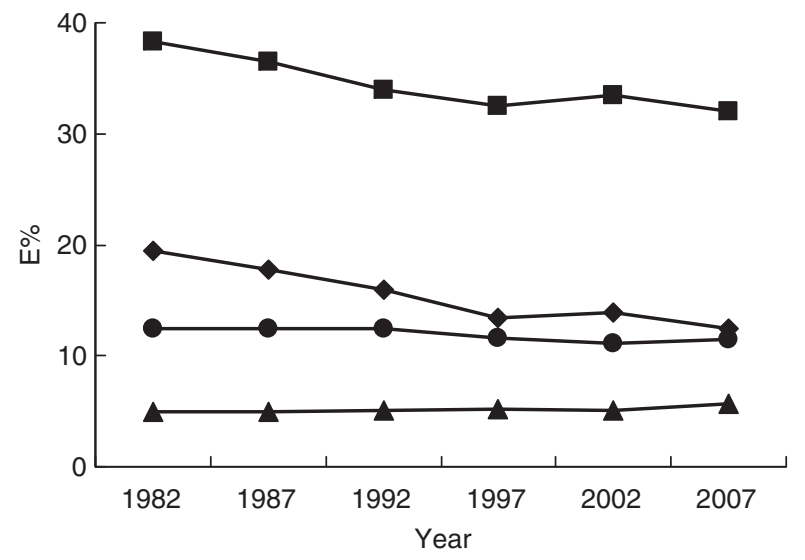

Fig. 5 The trends of total fat and fatty acid intakes (recommended levels in parenthesis) according to the national FINDIET surveys 1982-2007 in Finland: - - total fat $(\sim 30$ $\mathrm{E} \%) ; \sim$, SFA ( $10 \mathrm{E} \%) ; \multimap-$ MUFA (10-15 E\%); $\rightarrow$, PUFA (5-10 E\%) then ${ }^{(29)}$. Since 1992, nutritional status has been monitored in smaller sub-samples of the National FINRISK Studies. The main nutrients of interest have been vitamin D, vitamin C, folate, iron and iodine ${ }^{(30-33)}$.

\section{Challenges of dietary monitoring in the future}

At the moment the dietary monitoring system as well as the other health monitoring systems in Finland cover the majority of the different aspects of diet and eating habits, and include most geographical areas in Finland and also widely different population groups including the elderly (Fig. 6). The main challenge is the lack of dietary data on children. The only national data source is the Annual National School Health Survey that covers children aged 15-18 years. These surveys are carried out anonymously and gathered self-reported data on health behaviours ${ }^{(34)}$. There is no repeated national data source on younger children's diet or eating habits. From some large crosssectional and cohort studies, such as the Cardiovascular Risk in Young Finns Study (the LASERI study) ${ }^{(35)}$, and the Finnish Type 1 Diabetes Prediction and Prevention Project $^{(36)}$, good data on children's nutrition have, however, been obtained. Since 2006, the Child Health Monitoring Project (LATE) has developed a national system to collect health and health-related behavioural data on children directly from the child health-care and school health-care systems that in Finland cover almost $100 \%$ of the target population aged $0-15$ years $^{(37)}$. However, this brings only a partial solution as assessment of diet during regular health checks is challenging and not usually possible except by

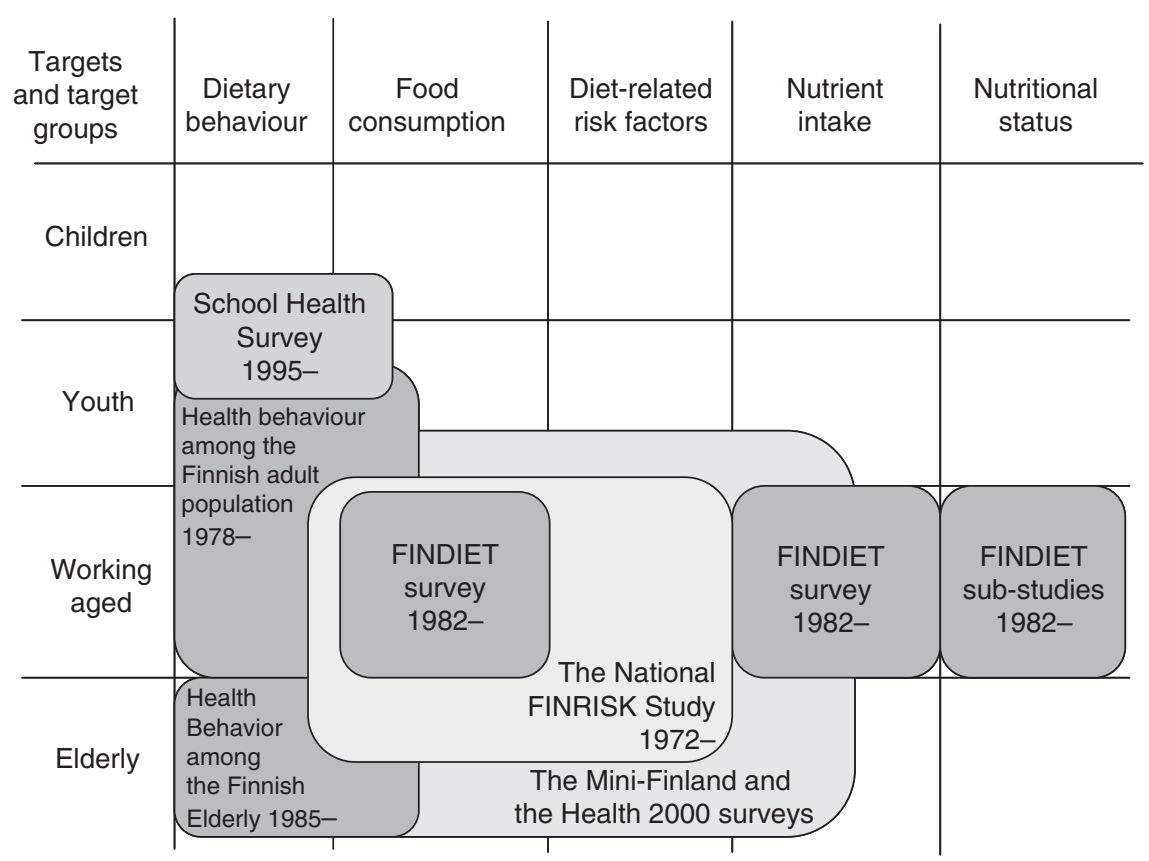

Fig. 6 Coverage of dietary monitoring targets and population groups by different currently conducted national monitoring approaches including dietary information in Finland 
some simple measures. More detailed assessment of dietary information requires special survey techniques.

Recently, several international approaches have been established to harmonise health monitoring especially in Europe $^{(38)}$. The European Union has launched several programmes on common indicators and monitoring approaches related to different health topics. This creates great challenges for the national monitoring systems. It is very important to get comparable data with other countries and to keep the national trends which are easily destroyed if the methodology is changed between surveys. There are also initiatives to harmonise nutrition monitoring in Europe. On the basis of the Finnish experience, combining the dietary monitoring with other health monitoring strategies has been a wise solution enabling the rich use of data.

\section{Public health implications}

These various regularly repeated monitoring approaches including different measures of diet and eating habits are nationally unique sources of dietary information. Data is widely used in monitoring the Finnish diet, influencing national policies and dietary recommendations, affecting and supporting the development of a public health supportive food industry as well as largely for research. The individual social security numbers of inhabitants in Finland enable the linkage of survey data to national administrative registers, thus survey participants can be followed-up and their disease and death endpoints can be recorded. This clearly increases the value of large population-based data sets for epidemiological research. Individual-based information also makes it possible to utilise data for more informative reporting, such as the production of regional maps on health promoting diet and related risk factors ${ }^{(39)}$. Reporting data in visually informative ways, e.g. taking advantage of the geographical information systems, serves the needs of policy and decision makers.

\section{References}

1. Ministry of Agriculture and Forestry (2008) Balance sheet for food commodities. http://www.mmmtike.fi/en/index/ statistics_information_services/publications/balance_sheet_ food_commodities.html (accessed March 2010).

2. Viinisalo M, Nikkilä M \& Varjonen J (2008) Elintarvikkeiden kulutusmuutokset kotitalouksissa vuosina 1966-2006 (In Finnish, summary in English: changes in the consumption of foods in households during the years 1966-2006). Publications of the National Consumer Research Centre 7/2008. http://www.kuluttajatutkimuskeskus.fi/files/5246/ 2008_07_julkaisu_elintarvikkeiden_kulutusmuutokset.indd. pdf (accessed March 2010).

3. Helakorpi S, Paavola M, Prättälä R et al. (2009) Suomalaisen aikuisväestön terveyskäyttäytyminen ja terveys, kevät 2008. Health Behaviour and Health among the Finnish
Adult Population, Spring 2008 (In Finnish, summary in English). Reports of the National Institute for Health and Welfare 2/2009. Helsinki: Helsinki University Print.

4. Laitalainen E, Helakorpi S \& Uutela A (2008) Eläkeikäisen väestön terveyskäyttäytyminen ja terveys keväällä 2007 ja niiden muutokset 1993-2007 - Health Behaviour and Health among Finnish Elderly, Spring 2007, with Trends 1993-2007 (In Finnish, summary in English). Publications of the National Public Health Institute B14/2008. Helsinki: Helsinki University Print.

5. Hasunen K, Pekkarinen M, Koskinen E et al. (1976) The food consumption and nutrient intake in Finland from 1966 to 1972 (In Finnish, summary in English). Report of the Social Insurance Institution ML9.

6. Järvinen R (1996) Epidemiological Follow-up Study on Dietary Antioxidant Vitamins. Results from the Finnish Mobile Clinic Health Examination Survey. The Social Insurance Institution, studies in social security and health 11. Helsinki: Kelan omatarvepaino.

7. Aromaa A, Heliövaara M, Impivaara O et al. (1989) Terveys, toimintakyky ja hoidontarve Suomessa. Mini-Suomi-terveystutkimuksen perustulokset. Publications of the Social Insurance Institution AL:32. Helsinki: Kansaneläkelaitos.

8. Seppänen K \& Karinpää A (1986) Suomalaisen ruokavalion laatu. Mini-Suomi terveystutkimuksen ravintokyselyn tulokset. (In Finnish, title in English: The quality of the Finnish diet. Helsinki: Kansaneläkelaitos.

9. Montonen J, Männistö S, Sarkkola C et al. (2008) Ravinnonsaannin väestörybmittäiset erot. Terveys 2000 - tutkimus (In Finnish, abstract in English: Sociodemographic differences in diet. Health 2000-survey). Publications of the National Public Health Institute B38/2008. Helsinki: Hakapaino Oy.

10. Heistaro S (editor) (2008) Methodology Report - Health 2000 Survey. Publications of the National Public Health Institute B26/2008. Helsinki: Hakapaino Oy.

11. Puska P, Salonen JT, Nissinen A et al. (1983) Change in risk factors for coronary heart disease during 10 years of a community intervention programme (North Karelia project). Br Med J (Clin Res Ed) 287, 1840-1844.

12. The World Health Organization MONICA Project (monitoring trends and determinants in cardiovascular disease): a major international collaboration (1988) WHO MONICA project principal investigators. J Clin Epidemiol 41, 105-114.

13. Peltonen M, Harald K, Männistö S et al. (2010) Kansallinen FINRISKI 2007 -terveystutkimus - Tutkimuksen toteutus ja tulokset. The National FINRISK 2007 Study - Survey methods and results (In Finnish, summary in English). Publications of the National Public Health Institute B34/2008. Helsinki: Helsinki University Print. Int J Epidemiol 39, 504-518.

14. Vartiainen E, Laatikainen T, Peltonen M et al. (2009) Thirtyfive-year trends in cardiovascular risk factors in Finland. Int J Epidemiol (Epublication ahead of print version).

15. Uusitalo U, Pietinen P \& Leino U (1987) Food and Nutrient Intake among Adults in East and Southwest Finland - A Dietary Survey of the FIN-MONICA Project in 1982. Publications of the National Public Health Institute B1/1987. Helsinki: Government Printing Centre.

16. Kleemola P, Virtanen M \& Pietinen P (1994) The 1992 Dietary Survey of Finnish Adults. Publications of the National Public Health Institute B2/1994. Helsinki: Helsinki University Print.

17. Anttolainen M, Javanainen J, Kaartinen P et al. (1998) The 1997 Dietary Survey of Finnish Adults. Publications of the National Public Health Institute B8/1998. Helsinki: Hakapaino Oy.

18. Männistö S, Ovaskainen ML \& Valsta L (editors) (2003) The National FINDIET 2002 Study (In Finnish, tables, figures and summary in English). Publications of the National Public Health Institute B3/2003. Helsinki: Hakapaino Oy. 
19. Paturi M, Tapanainen H, Reinivuo H et al., (editors) (2008) FINRAVINTO 2007-tutkimus. The National FINDIET 2007 Survey (In Finnish, summary in English). Publications of the National Public Health Institute B23/2008. Helsinki: Helsinki University Print.

20. Reinivuo H, Hirvonen T, Ovaskainen M et al. (2010) Dietary survey methodology of FINDIET 2007 with a risk assessment perspective. Public Health Nutr (in this issue).

21. Pietinen P, Paturi M, Reinivuo H et al. (2010) FINDIET 2007 survey. Public Health Nutr (in this issue).

22. Maurer J, Taren DL, Teixeira PJ et al. (2006) The psychosocial and behavioral characteristics related to energy misreporting. Nutr Rev 64, 53-66.

23. Becker W, Foley S, Shelley E et al. (1999) Energy underreporting in Swedish and Irish dietary surveys: implications for food-based dietary guidelines. Br J Nutr 81, Suppl. 2, S127-S131.

24. Becker W \& Welten D (2001) Under-reporting in dietary surveys - implications for development of food-based dietary guidelines. Public Health Nutr 4, 683-687.

25. Hirvonen T, Männistö S, Roos E et al. (1997) Increasing prevalence of underreporting does not necessarily distort dietary surveys. Eur J Clin Nutr 51, 297-301.

26. Bailey RL, Mitchell DC, Miller C et al. (2007) Assessing the effect of underreporting energy intake on dietary patterns and weight status. I Am Diet Assoc 107, 64-71.

27. Lamberg BA (2003) Kupukaula on jo menneisyyttä. Struuman historiaa Suomessa (In Finnish, summary in English: History of endemic goitre in Finland). Vammala: Vammalan kirjapaino $\mathrm{Oy}$.

28. Laatikainen T, Pietinen P, Valsta L et al. (2006) Sodium in the Finnish diet: 20-year trends in urinary sodium excretion among the adult population. Eur J Clin Nutr 60, 965-970.

29. Alfthan G (2010) Nationwide supplementation of sodium selenate to commercial fertilizers. History and 20-year results from the Finnish selenium monitoring program. In Food Based Approaches (FBAs9 for Combating Micronutrient Deficiencies). FAO (in press).

30. Matilainen T, Vartiainen E, Puska P et al. (1996) Plasma ascorbic acid concentrations in the Republic of Karelia,
Russia and in North Karelia, Finland. Eur J Clin Nutr $\mathbf{5 0}$, 115-120.

31. Lamberg-Allardt CJ, Outila TA, Kärkkäinen MU et al. (2001) Vitamin D deficiency and bone health in healthy adults in Finland: could this be a concern in other parts of Europe? J Bone Miner Res 16, 2066-2073.

32. Alfthan G, Laurinen MS, Valsta LM et al. (2003) Folate intake, plasma folate and homocysteine status in a random Finnish population. Eur J Clin Nutr 57, 81-88.

33. Lahti-Koski M, Valsta LM, Alfthan G et al. (2003) Iron status of adults in the capital area of Finland. Eur J Nutr $\mathbf{4 2}$, 287-292.

34. National Institute for Health and Welfare. The School Health Survey. http://www.stakes.fi/kouluterveys//EN/ index.htm (accessed March 2010).

35. Åkerblom HK, Viikari J, Uhari M et al. (1984) A study of cardiovascular risk factors and their determinants in Finnish children. Ann Clin Res 16, 23-33.

36. Virtanen SM, Kenward MG, Erkkola M et al. (2006) Age at introduction of new foods and advanced beta cell autoimmunity in young children with HLA-conferred susceptibility to type 1 diabetes. Diabetologia 49, 1512-1521.

37. Mäki P, Laatikainen T, Koponen P et al. (2008) Lasten ja nuorten terveysseurannan kehittäminen - LATE-hanke (In Finnish, abstract in English: development of child health monitoring system - LATE project. Publications of the National Public Health Institute B28/2008. Helsinki: Yliopistopaino. http://www.ktl.fi/attachments/suomi/julkaisut/ julkaisusarja_b/2008/2008b28.pdf (accessed March 2010).

38. Tolonen H, Koponen P, Aromaa A et al. (editors) (2008) Recommendations for the Health Examination Surveys in Europe Publications of the National Public Health Institute B21/2008. Helsinki: Helsinki University Print.

39. Similä M, Taskinen $\mathrm{O}$, Männistö S et al. (2005) Terveyttä edistävä ruokavalio, lihavuus ja seerumin kolesteroli karttoina (In Finnish, abstract in English: maps on health promoting diet, obesity and serum cholesterol in Finland). Publications of the National Public Health Institute B20/2005. http://www.ktl.fi/attachments/suomi/julkaisut/julkaisusarja b/2005/2005b20.pdf (accessed March 2010). 